\title{
ISLAM IN THE HISTORY OF RUSSIA: CONFRONTATION VS. COOPERATION
}

\author{
Lubomír Čech
}

University of Economics in Bratislava, Slovak Republic

The purpose of this paper is to highlight the key stages in the development of relations between Russia and Islam and to give a concise analysis of their political and cultural consequences. The article is divided into two parts. The first part outlines the history of Islam in Russia. The second part deals with the Soviet Union's stance on the Islamic faith. We can state that Islam in Russia has deep historical and cultural roots. The very fact that this religion has survived through the centuries of confrontation and cooperation proves how unique the relations between Russia and the Muslim world are. The history of Islam in Russia offers lessons to be learned as the religion as such poses great challenges to this multi-religious and multi-ethnic country.

Keywords: Islam; Muslim population; Russia; the Soviet Union; cultural roots

\section{Introduction}

Islam is the world's second largest religion after Christianity. The same applies to the Russian Federation. Even though Russian Muslims belong to the global Ummah, they have their own specific and unique features that distinguish them from their fellow believers in other countries.

These characteristics result from the intricate interactions between local traditions and the predominant Russian and Soviet cultural policies. If we want to comprehend contemporary challenges brought by Islam in the Russian Federation, we need to understand the relationships between Russia and Islam in their historical context. That is why the purpose of this paper is to highlight the key stages in the development of relations between Russia and Islam as well as to give a concise analysis of their political and cultural consequences.

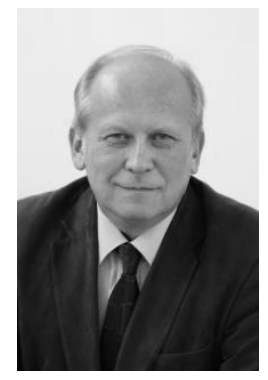

\section{Lubomír Čech}

Doctor of History, Associate Professor

Head of the Department of International Political Relations, Faculty of International Relations, University of Economics in Bratislava, Slovak Republic

ORCID ID: 0000-0002-8406-9480

Research interests: international relations; Islam and its influence on political and economic relations; security relation between the Asian countries.

E-mail: lubomir.cech@euba.sk 


\section{ISLAM IN THE HISTORY OF RUSSIA}

We have been using qualitative data as our resources, these have been mostly scientific texts. As a result, we have chosen a qualitative research method.

Russia's relationships with Islam have already been studied by Malashenko (2010), Yemelianova (2002, 2010), Crews (2006), Hunter (2003).

The history of these relationships has been also explored by Ramet (1993), as well as by Bennigsen \& Wimbush (1986).

\section{History of Islam in Russia}

The history of Islam in Russia begins with the Rashidun period. In the mid seventh century, Islam first spread through the territory of today's Dagestan and then throughout the North Caucasus region. In another part of what is Russia today, in the Upper Volga region, Islam penetrated through trade relations with the Muslim world. The first Muslim state within the boundaries of today's Russia was Volga Bulgaria, which is now the territory of Tatarstan.

Due to its strategic position, where the Kama river joins the Volga, Volga Bulgaria became a crucial Eurasian trade meeting point. In addition, this region was playing a significant role in Islam's penetration into other parts of modern Russia.

The adoption of Islam by Volga Bulgaria had profound political and cultural consequences for the proto-Russians. It largely influenced religious policies followed by the rulers of the Kievan Rus, which was founded in Western Eurasia in the late ninth century after the Varangian (Vikings) invasions.

In 988, Vladimir, the ruler of the Kievan Rus, adopted Orthodox Christianity as the state religion. To some extent, this Vladimir's decision initiated future distinctions between the Slavic world and the Catholic West, and also between Judaism in the Khazar Empire and Islam in Volga Bulgaria along with other eastern and southern states. The adoption of Christianity by Kiev elites did not then have dramatic effects on Russia's relations with its non-Christian Eurasian neighbours.

Flexibility and tolerance of the Hanafi Madhab in Volga Bulgaria allowed Muslim religious leaders to accept and acknowledge local traditions and rituals which had existed before the arrival of Islam. According to some historical sources, wars between Volga Bulgars and the proto-Russians were not religious or ethnic conflicts, they were driven solely by economic and political goals (Yemelianova, 2002: 8-9).

From the 13th to the 15th century, Volga Bulgars and the proto-Russians were both made subject to the Golden Horde, the western province of the vast Mongol Empire. Indeed, this period can be regarded as the second stage in the history of Islam in Russia. Similar to other parts of the Mongol Empire, the Golden Horde was a multi-ethnic and multicultural political entity that was ruled by khans at the top of the nomadic military hierarchy. In the early 15th century, it disintegrated into several independent Muslim khanates (Crimean Khanate, Kazan Khanate, Astrakhan Khanate, Nogai Horde and Siberian Khanate).

As a result, Islam was dominating on a huge area of what is now Russia's territories until these khanates were conquered by the Russian Empire in the 16th century.

According to G. Yemelianova, the Russian Orthodox Church played the key role in suppression of Islam. It was actively promoting the concept of "Moscow as the Third Rome" and the tsar as its divine leader and guardian. Repression of Islam as well as forced 
Christianisation and Russification were the major features of the Moscow's policy that was aimed at integrating multiple very diverse territories into one centralized Russian state.

This policy was also aimed at the integration of these territories into the Russian administrative system along with militarization and economic colonization (Pilkington \& Yemelianova, 2003: 23-24).

As Hunter (2004) pointed out, Moscow's policy reflected the character of the Russian state and its ideology. The concept of Russian statehood and nationality emerged during the reign of Ivan the Terrible, when Russia began its expansion into Muslim territories.

One of the most important and deeply rooted aspects of Russian statehood was the legacy of the Byzantine Empire where merger of church and state functions used to be also observed. In Russia, this concept was broadened even further - merging religion, ethnic affiliation and nationality together.

That is why being Russian meant being an Orthodox Christian and an ethnic Slav as well. Integration of Muslim countries disrupted this ethnic and religious unity. The preservation of its Orthodox Christian character required assimilation of Muslims, which would ensure religious and national homogeneity inside the developing empire (Hunter, 2004: 7).

Muslim national archives and libraries were destroyed by ardent Orthodox "civilians". Demolitions of mosques, closures of religious schools, forced Christianization and deportations of those who refused to convert made large numbers of Muslims flee to less climatically hospitable regions or to other countries. Muslims in many parts of the VolgaUral region and the North Caucasus became minorities on the territories that once belonged to their ancestors. In fact, they have been coping with their minority status until the present day.

During the reign of Peter the Great, Russia underwent radical reforms which were supposed to break its economic and cultural stagnation and push it into the westward direction. However, Russian rulers continued their expansion through war campaigns and suppressions of the national and religious opposition (Sakwa, 1993: 394).

When Catherine the Great came to power, she adopted an attitude of tolerance towards Muslims in the Russian Empire. Her liberal religious policy was associated with her concept of state, which she regarded as an empire along with other existing or emerging European empires rather than an ethnically and religiously homogeneous national state. She promoted active cooperation with Russia's Muslim institutions in order to inspire greater loyalty to Saint Petersburg.

The "Toleration of All Faiths" Edict of 1773 permitted Muslims to practise all their traditions for the first time in the era of Russian imperialism. This edict also banned religious persecutions. As a result, the Muslim community started to be gradually integrated into various power structures. These reforms also resulted in the lifting of some restrictions on Muslim trading activities, the construction of new mosques and religious schools and the removal of all the restrictions on Islamic literature.

Moreover, the year 1804 saw the establishment of the Kazan Federal University. These enlightened policies brought in many advantages and benefits for Russia, including economic prosperity and cultural development of the Volga-Ural region. The cities of Kazan, Ufa and Orenburg became important centers of the Islamic education. What is more, Tartar merchants started to act as the main intermediaries in the trade between Russia and its Muslim neighbors in Iran, Afghanistan, India and Western China (Hunter, 2004: 9-10). 


\section{ISLAM IN THE HISTORY OF RUSSIA}

Russia's penetration into the Caucasus and Central Asia meant that more and more Muslims were integrated into the Russian Empire, which consequently raised the issues relating to its attitudes towards Islam and Muslims. In Central Asia and the Caucasus region, Russia pursued its colonial policies, which were aimed at extending its political control without disrupting local government structures and exploiting contested territories - giving land to Russian peasants, obtaining natural resources for the Russian industry and gaining control over Russian merchandise markets.

These goals and the extent of religious and cultural freedom that Muslims were allowed were driven particularly by the preferences of Russian authorities responsible for administration of different Muslim regions (Haghayeghi, 1995: 7-9). The North Caucasus was actually unstable throughout the entire Russian imperial rule, thus, Russia was concerned more about the security of this region rather than its cultural and religious issues.

Successors of Catherine the Great did not pursue her enlightened policies. The religious persecution methods, which had been used before her rule, were again adopted in the mid of19th century. Imperial Muslim assimilation policies were implemented at different pace, in different times and in different parts of the empire.

Thus, it comes as no surprise that Muslims responded to Russian rule by armed resistance and regular revolts accompanied by less aggressive attempts to keep religious and cultural traditions alive.

Nevertheless, Muslims did not reject cooperation with their Russian rulers provided that they were granted an adequate extent of religious and cultural freedom and were treated as partners with less authority. Despite its occasional harsh treatment of Russian Muslims, the Tsarist regime sometimes used more tolerant approaches, including limited autonomies granted to some Muslim regions (Bennigsen \& Broxup, 1983: 24-25).

Not only had Islam survived the decades of oppression on the hostile Russian territories, but it also underwent its revival in the early 20th century, which considerably improved religious, political, social and economic life of the Russian Muslims and positively influenced the Muslim world as a whole. Imperial assimilation policies and religious persecutions of Muslims in the second half of the 19th century could not completely eliminate the effects of Catherine the Great's reforms.

Islamic publishing activities and new opportunities of travelling to different parts of the empire, the Central Asia in particular, led to a powerful reform movement and resurgence. Famous Muslim Tartar intellectuals advocated the creative and flexible potential of Islam and its compatibility with technological and economic progress. These ideas paved the way for language, educational and social reforms in the Russian Muslim community.

In the 1880s, Ismail Gasprali, a renowned Muslim scholar and teacher of the Crimean Tatar origin, introduced a new teaching method aimed at reforming Muslim primary schools. His educational movement soon evolved into a wider sociopolitical and cultural phenomenon referred to as Jadidism.

The wave of peasant uprisings, worker strikes and military mutinies, which took place between 1904 and 1907 and was known as the Russian Revolution of 1905, created a more liberal atmosphere in the country. The turmoil and unrest made the emperor Nicolas II issue a document called October Manifesto, in which he promised to grant civil liberties to all the Russian citizens, including the freedom of religion, speech, assembly and association as well as participation in the Duma and universal suffrage for all. 
These reforms allowed Russian Muslims to unite, talk about their problems and get involved in politics for the first time under the imperial Russian rule. The All-Russian Muslim Congress, which was held in Saint Petersburg in 1905, resulted in the founding of the Union of the Muslims of Russia, a central authority designated to coordinate collective action of all Russian Muslims (Kanlidere, 1997: 100-101).

\section{Islam in the Soviet Union}

The Islamic resurgence in Russia and the political activism of Russian Muslims did not last long. The promises of land giving, peace and social justice made by the Bolsheviks in October 1917 appealed to many poor and desperate people in Russia, including its $18 \mathrm{mln}$ Muslims.

However, Muslims were concerned about the Bolsheviks' atheism as well as their attitudes towards private property and social equality. As a result, the majority of the Islamic traditionalists refused to acknowledge legitimacy of the Bolshevik rule and joined open or secret opposition. Even though the overthrow of the Tsarist regime offered Russian Muslims new opportunities to gain more cultural, religious and political autonomy, the Bolsheviks' seizure of power ultimately proved to be even more detrimental to the Muslim community than the Russian imperial rule in every aspect, religion and culture especially.

The original after-revolutionary and somewhat liberal approach to Islam was replaced by an aggressive oppression of religious and national identity under Stalin's rule. The Stalinist repression involved mass closures of mosques and educational institutions as well as elimination of Muslim religious scholars, intellectuals and political elites.

Publishing of the Islamic literature and periodicals was suspended and the books that had been published earlier were banned. The new Soviet system of universal compulsory education was based on the Communist atheist indoctrination and the Soviet interpretation of history defined the prism of class conflict, in which national and religious identities were portrayed as primitive and insignificant. The Bolshevik leaders were suspicious of all the Muslims under the Soviet rule, regardless of whether or not they were opponents of the rule, "modernist" Muslims or even members of the Bolshevik Party.

The Great Patriotic War against Nazi Germany presented new challenges for RussiaMuslims relationships in the Soviet Union. Hitler promised Soviet Muslims political independence in exchange for their cooperation. Stalin responded to this German propaganda by appealing to transnational patriotism of the Soviet multi-faith and multi-cultural population (Yemelianova, 2002: 47).

Patriotic propaganda and the pro-Islamic concessions made by Stalin's rule managed to achieve their objectives - the majority of the Soviet Muslims became more loyal, the efforts of the Nazis to gain adherents among the Soviet Muslim community were in vain and Islamic religious leaders promoted jihad against Hitler. At the end of the war, however, the Muslims in the Soviet Union paid a very high price for their alleged lack of loyalty. In 1944, all ethnic Chechens, Ingushs, Kalmyks, Karachays, Crimean Tatars and other people were accused of collaboration with the Nazis and deported to Siberia and Central Asia overnight.

In 1945, straight after the war was over, the Soviet Union reintroduced its anti-religious and anti-national propaganda again. There were concerns that any religious revival, like the one the country experienced during the war, might cast doubt on the official Communist ideology. 


\section{ISLAM IN THE HISTORY OF RUSSIA}

As a result, the Communist Party adopted a series of resolutions aimed at eradicating religious beliefs among Soviet people and "emancipating" national cultures from religion. These new policies severely restricted social, educational and cultural activities of religious institutions and communities (Ro'i, 2000: 203-205).

Soviet leader Nikita Khrushchev is best known for his de-Stalinization policies, which made Soviet society socially and politically somewhat less repressive. In terms of religion, however, he was in favor of a reformed and revived anti-religious policy. The attitudes of the Soviet Union towards Islam changed during Brezhnev's rule, primarily due to the changed foreign policy interests. As a result, Islam could be secretly practiced.

In the mid-1960s, the USSR consolidated its influence in the Middle East and began to focus on the relations with the Persian Gulf and the Eastern Mediterranean. Its prospects here improved thanks to the revolutionary and anti-western movements that swept through some areas in the Middle East. In this new environment, traditional Russian and Soviet policies that considered Islam to be an underdeveloped and barbarian religion would have threatened Soviet political ambitions in the Muslim world (Anderson, 1994: 66-67, 135-136).

In the late 1980s, under the rule of Mikhail Gorbachev, Soviet political elites began to realize that the decades of persecution and repression had not eradicated religion and that it was no longer an enemy but a potential ally that could participate in the promotion of reforms.

The year 1990 saw the enactment of several laws on the protection of press freedom, freedom of conscience, freedom of assembly and religious liberty. Freedoms associated with with the so-called "glasnost" revealed long-term ethnic and religious discrimination of many Soviet citizens. In addition, they prompted the dynamics that, combined with some other factors, gradually led to the dissolution of the Soviet Union as such. Lifted restrictions on religious beliefs, more intense religious activities and contacts between post-Soviet Muslims and the rest of the Islamic world as well as increased funding were all the factors that contributed to Islamic awakening in the then newly established Russian Federation.

In the mid-1990s, however, Kremlin changed its regional policies and began restoring the de facto unitarist Russian state as well as the administrative and military suppression of national and religious regional separatism. These new attitudes then resulted in two Chechen Wars, which intensified Islamophobia.

Formulation and implementation of coherent national and religious policies focused on ethnic and religious pluralism remain one of the greatest challenges the Russian Federation is currently facing (Pilkington \& Yemelianova, 2003: 47).

\section{Conclusion}

Even though Russia is rarely associated with Islam and Islamic identity in general, this faith has deep historical and cultural roots within the territory of what is now the Russian Federation. Muslims have contributed to the development and growth of Russian civilization for centuries. Therefore, Islam is an inseparable part of Russian history.

However, it is not easy to determine precisely when Islam emerged in Russia due to the fact that the countries into which Islam penetrated at the beginning of its expansion were not part of Russia, but were annexed by the Russian Empire a few centuries later.

Muslims in the Russian Empire were often subjected to forced assimilation and

repressions. Nevertheless, there were also times when Russian rulers and Muslim religion 
were able to coexist. The very fact that Islam has survived through the centuries of Russian colonialism as well as the Islamic revival of the early 20th century itself prove how unique the relations between Russia and the Muslim world are and how powerful the influence of Islam in this country is. Even though the Soviet Union managed to eliminate the significant role of religion in the society, the 1990s changed everything. The fall of the USSR brought Islam its legal recognition in Russian society.

The Russian Federation has currently the largest Muslim population of all the European countries. It is a unique example of how Muslim and Christian communities have developed and interacted for centuries of political and ethnic confrontation and external influences. Stages in the history of the relations between Russia and Muslims that this paper examines cast doubt on an idealistic view of Russia's history, according to which its nations and cultures have always coexisted in harmony. On the other hand, the periods of cooperation indicate that Islam and Russia do not have to be implacable adversaries, despite their problematic relationships.

\section{References:}

Anderson, J. (1994). Religion, state and politics in the Soviet Union and successor states. Cambridge.

Bennigsen, A. \& Broxup, M. (1983). The Islamic Threat to the Soviet State. New York.

Bennigsen, A. \& Wimbush, S. E. (1986). Muslims of the Soviet Empire: A guide. Rutlege-press.

Haghayeghi, M. (1995). Islam and Politics in Central Asia. New York.

Hunter, S. (2004). Islam In Russia: The Politics Of Identity And Security. London - New York.

Kanlidere, A. (1997). Reform within Islam: The Tajdid and Jadid Movement: Among the Kazan Tatars (1809-1917): Conciliation or Conflict? Istanbul.

Malashenko, A. (2010). Islam in Russia: Religion and Politics. Moscow.

Pilkington, H. \& Yemelianova, G. M. (2003). Islam in Post-Soviet Russia. London - New York.

Ramet, S. P. (1993). Religious policy in the Soviet Union. New York.

Ro'i, Y. (2000). Islam in the Soviet Union: From the World War II to Perestroika. London.

Crews, R. D. (2006). For Prophet and Tsar: Islam and Empire in Russia and Central Asia. London.

Sakwa, R. (1993). Russian Politics and Society. London - New York.

Yemelianova, G. M. (2002). Russia and Islam: A Historical Survey. New York.

Yemelianova, G. M. (2010). Radical Islam in the Former Soviet Union. London - New York.

Paper submitted

Paper accepted for publishing

Paper published online
11 September 2021

22 November 2021

31 January 2022 